\title{
Hormones and Receptors in Endometrial Cancer
}

\author{
David Bender, M. D. ${ }^{1}$, Thomas Buekers, M.D. ${ }^{1}$, Kimberly K. Leslie, M.D. ${ }^{1,2}$
}

Key Words: hormones, steroids, uterus, endometrium, estrogen, progestin, receptors, endometrial cancer

\begin{abstract}
The uterine endometrium is exquisitely sensitive to hormones, in particular estrogen and progesterone and to a lesser extent androgens and glucocorticoids. These hormones tightly regulate the complex functioning of the female reproductive tract and are intimately involved in controlling the growth, development, and remodeling of reproductive tissues as well as the cyclic changes that occur during the menstrual cycle. Steroids function by binding to nuclear receptor proteins that act as transcription factors to modulate the expression of genes, though many non-genomic effects for steroids have also been described. An imbalance of the hormones leads to cancer. In particular, endometrial carcinogenesis is related to overexposure to estrogen that is not balanced by the differentiating effects of progesterone and potentially other steroid hormones, including androgens and glucocorticoids. This review summarizes steroid hormone action in the endometrium, describes the relative localization of hormone receptors in the normal endometrium and in endometrial cancer, and highlights key clinical trials that have attempted to restore the balance of hormones and thus prevent recurrence of endometrial cancer.
\end{abstract}

\begin{abstract}
${ }^{1}$ The Department of Obstetrics and Gynecology, The Carver College of Medicine, The University of lowa, lowa City, lowa, USA

${ }^{2}$ Holden Comprehensive Cancer Center, The Carver College of Medicine, The University of lowa, lowa City, lowa, USA
\end{abstract}

\section{Introduction}

The uterine endometrium is exquisitely sensitive to hormones. The best studied and most relevant steroids that participate in endometrial cellular processes are the estrogens and progestins. These hormones tightly regulate the complex functioning of the female reproductive tract. Both hormones are intimately involved in controlling the growth, development, and remodeling of reproductive tissues as well as for the cyclic changes that occur during the menstrual cycle. Estradiol is the principal estrogen, although both estrone (a precursor to estradiol) and estriol (a metabolic product of estradiol) also have estrogenic actions. The most

Please cite this paper as: Bender D, Buekers T, Leslie KK. Hormone receptors and endometrial cancer. Proc Obstet Gynecol. 2011 July;2(1):Article 1 [ 25 p.]. Available from: http://ir.uiowa.edu/pog/. Free full text article.

Corresponding author: Kimberly K. Leslie, M.D. Department of Obstetrics and Gynecology, University of Iowa, 31140-A PFP, 200 Hawkins Drive, Iowa City, IA 52242. Telephone (319)356- 1976. kimberlyleslie@uiowa.edu

This is an Open Access article distributed under the terms of the Creative Commons Attribution 3.0 Unported License (http://creativecommons.org/licenses/by/3.0), which permits unrestricted use, distribution, and reproduction in any medium, provided the original work is properly cited. 
relevant naturally occurring progestins are progesterone and its 17-hydroxy derivative. These steroids function by binding to nuclear receptor proteins that act as transcription factors to modulate the expression of genes. In human cells, two forms of the estrogen receptor (ER) have been described to date, the originally described $E R-\alpha$, encoded by a gene on chromosome $6{ }^{1}$, and the more recently described ER- $\beta$, encoded by a gene on chromosome $14^{2}$. The progesterone receptor (PR) also exists in more than one form. $P R$ isoforms $A$ and $B$ have been well characterized ${ }^{3}$. A third truncated form, PRC, has also been reported ${ }^{4}$. PR is different than $E R$ in that the same gene on chromosome 11 encodes all of the PR variants described to date.

The existence of ER was first deduced in the late 1950's, but ER was not cloned and sequenced until 1984 5. Interestingly, and quite pertinent to the discussion of mutant ERs below, the receptor as originally cloned and sequenced contained a point mutation that substantially reduced its activity compared to the wild type (wt) receptor, a finding which will be expanded upon below. Much more recently, a second ER was identified ${ }^{2}$ and is referred to as ER- $\beta$; consequently the originally identified receptor is now referred to as ER- $\alpha$.

\section{Details of Steroid Receptor Structure and Function}

ER and PR are members of a large class of receptors generically referred to as the steroid-thyroid hormone receptor superfamily. All members of this family share certain common structural features. They are all encoded by multi-exon genes that produce proteins containing several functional domains, as depicted in Figure 1 using PR as an example. The domains of the steroid receptors are labeled $A$ through $F$ from the $\mathrm{N}$ to the $\mathrm{C}$ terminus, and were originally defined by separation by proteolytic cleavage, but have now been more rigorously characterized via molecular and biochemical methods. Although specific details vary to some degree from receptor to receptor, several common functional themes can be mapped to the various regions. The $A$ and $B$ domains participate in protein-protein interactions with additional modulator proteins that mediate the transcriptional activation of target genes. The $\mathrm{C}$ region contains the DNA binding domain, which has two zinc-finger motifs that serve to anchor the receptor to specific DNA recognition sequences. The $\mathrm{C}$ region also contains the nuclear localization sequence (NLS) necessary for shuttling the receptor into the nucleus. Region D consists of a relatively unstructured hinge region between the hydrophilic DNA binding domain and the more hydrophobic region $\mathrm{E}$. Region $\mathrm{E}$ itself contains the ligand binding pocket and also contains sequences that interact with additional modulator proteins, allowing the receptor to exert transcription regulatory effects as well. 


\section{Functional Domains of Progesterone Receptor A and B}
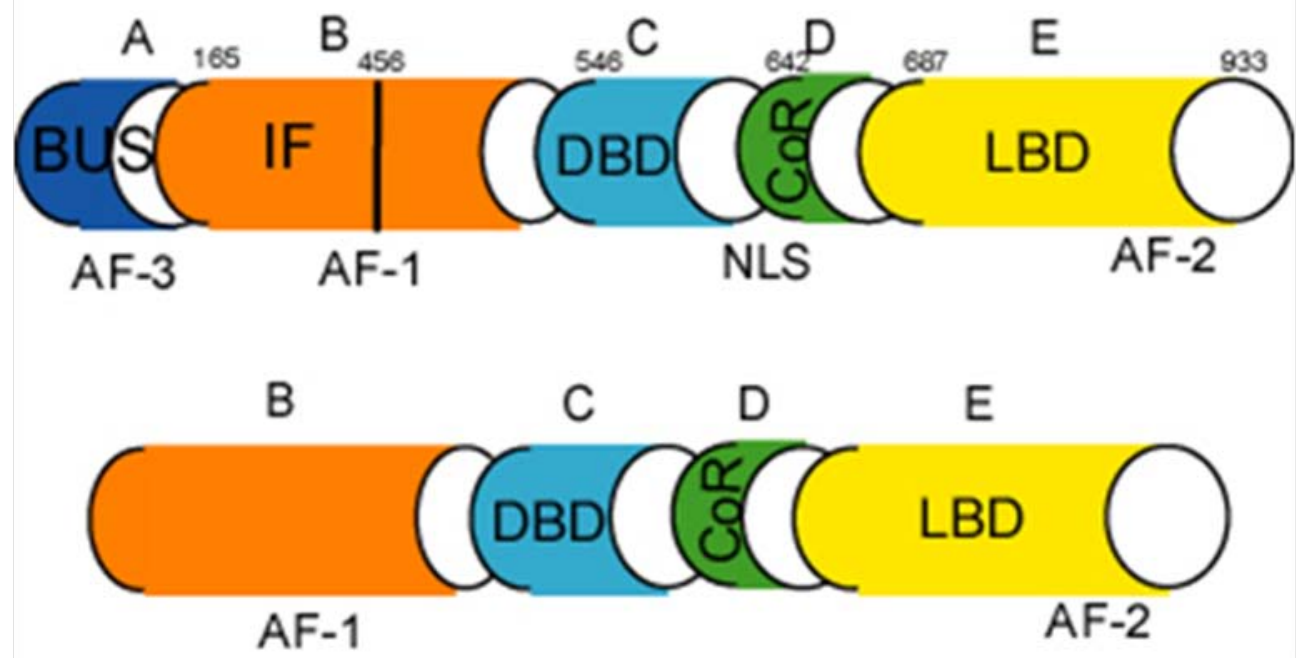

Figure 1.

Functional domains of progesterone receptor $A$ and $B$. The $A$ and $B$ isoforms of $P R$ arise from alternative promoters from the same gene. The $B$ isoform (upper figure) is identical in sequence to the $A$ isoform (lower figure) with the exception of the first 164 amino acids at the $\mathrm{N}$ terminus, termed the B upstream segment (BUS). The domains are divided into functional units A-E. IF = an inhibitory function area unmasked by the absence of BUS; DBD = the DNA binding domain; $\mathrm{CoR}=$ a hinge region known to bind to receptor co-modulators; $\mathrm{LBD}=$ the ligand (hormone) binding domain. AF 1-3 = activation functions required for gene transactivation and protein/protein interactions. The numbers noted above indicate the amino acids.

Steroid receptors function primarily as dimers, and sequences within regions $\mathrm{C}$ and $\mathrm{E}$ provide the interface for dimer formation. In the absence of hormone, receptors are monomers associated with chaperone proteins such as heatshock protein 90 as well as other factors; upon binding hormone, the receptor dissociates from its chaperones and dimerizes with another receptor molecule ${ }^{6}$. This paired, ligand-bound receptor then binds to DNA, interacts with other accessory proteins that modulate its function (described in more detail in subsequent sections) and exerts its effect on transcription of target genes.

\section{Receptor Isoforms}

\section{Estrogen Receptor Variants}

ER- $\alpha$ follows the basic structural outline of the steroid thyroid hormone receptor superfamily described above. ER stimulates transcription by means of distinct functions, performed by intrareceptor sequences, including a transcription activation function in the DNA binding region and two nonacidic transcription activation functions, TAF1 in the A/B region and TAF2 in the E/F region. ER- $\beta$ is structured similarly, with the following regional homology to ER alpha A/B: $20 \%$, C: $95 \%$ and E: $60 \%$ 2 
Some of the first indications that variant or mutant receptors exist came from breast and endometrial cancers. In the breast, many tumors initially express ER at levels above those found in non-malignant breast cells ${ }^{7}$, and while ER expression is a marker for well-differentiated breast cancers, the levels in many tumors are inappropriately high. Since estrogen induces PR expression in the breast ${ }^{8}$, PR levels generally correlate with ER and are a good prognostic factor for tumor responsiveness to antiestrogen therapy. However, some tumors are ER+/PR- or ER-/PR+. These phenotypes have been explained on the basis of mutant ER, and provided the first hints that abnormal ER may be present in breast tumors ${ }^{9}$. For an $\mathrm{ER}+/ \mathrm{PR}$ - tumor, it is predicted that the pathways leading to PR activation by ER are interrupted. One mechanism of interruption is a mutation in ER that prevents transactivation of the PR gene. For ER-/PR+ tumors, another type of ER mutant is predicted, namely, a constitutively active ER that can activate gene transcription but has a mutation in the hormone binding domain. Such a receptor would not be recognized by ligand binding assays, and the tumor would be considered ER negative.

In the endometrium, ER and PR are induced in the first half of the cycle and down-regulated in the luteal phase. Over $95 \%$ of all endometrial cancers express ER, and similar to early breast cancers, the concentration of ER is high - perhaps abnormally high. ER is a marker for differentiation, and PR is generally, but not always, present. Rarely, ER+/PR- tumors are identified. Such tumors tend to have a poor prognosis and do not respond to progestin therapy ${ }^{3}$.

Numerous reports of mutations leading to variant ER messages have appeared in the literature over the past two decades. The majority of these variants have been observed in ER- $\alpha$; however, in time, it is likely that variant forms of ER- $\beta$ will also be discovered. For example, the possibility that a longer form of ER- $\beta$ exists has been suggested ${ }^{10}$. Also, although not strictly related to a discussion of variant receptors, there has been one report suggesting that the ratio of ER- $\alpha$ to ER- $\beta$ may play a role in cancer development. In this study, it was found that ER positive tumors had a significantly higher ER$\alpha$ to ER- $\beta$ ratio than did adjacent normal tissue, but there was no difference in the ratio for ER negative tumors compared to adjacent normal cells ${ }^{10}$.

ER- $\alpha$ is expressed in the female and male reproductive tracts, breast, brain, bone, liver, vasculature, heart, kidneys, adrenals, and possibly other sites. ER- $\alpha$ was originally cloned from the prostate gland in rats ${ }^{2}$, but is now known to be widely expressed in humans and rodents. ER- $\beta$ is present at the mRNA level in many tissues including the male and female reproductive tracts, brain, bladder, breast, heart 11, and interestingly, in the ER- $\alpha$ knock-out (ERKO) mouse model described by Lubahn and colleagues ${ }^{12}$. Not surprisingly, the ratios of ER- $\alpha$ to ER- $\beta$ vary between organs. ER- $\alpha$ 
predominates in the rat uterus and in endometrial cancer cells and induces numerous growth-promoting genes ${ }^{2}$. $E R-\alpha$ also predominates in the stromal cells of the prostate; however, ER- $\beta$ is more highly expressed in the epithelial cells of the prostate. In the cerebral cortex and the pituitary, the distribution of the two ERs is similar, but in the rat hypothalamus, cerebellum, brain stem, and spinal cord, ER- $\beta$ is the most highly expressed.

As mentioned previously, ER- $\alpha$ and ER- $\beta$ are not splice variants, but are unique genes mapping to different chromosomes. Both receptors bind estrogens with approximately equal affinity, and they both bind antiestrogens 4-OH-tamoxifen, tamoxifen, and $\mathrm{ICl} 164384^{11}$. Both receptors also are likely to bind to the same promoter sequences, termed estrogen response elements, since their DBD regions differ by only one amino acid. However, with significant dimorphism in the $A / B$ domains of the $N$-termini of ER- $\alpha$ and ER- $\beta$, transcriptional activation of individual genes is likely to differ significantly between the two ERs ${ }^{13}$. The $A / B$ domain functions in intermolecular protein/protein interactions as well as intramolecular interactions with the C-terminus. These interactions have significant effects on the ability of receptor dimers to induce transcription. The transcriptionally active form of $E R$ is a ligand-bound dimer; ER- $\alpha$ and ER$\beta$ can form homo- and heterodimers (ER- $\alpha / E R-\alpha, E R-\alpha / E R-\beta$, ER- $\beta / E R-$ $\beta)$. The propensity of ER- $\alpha$ and $E R-\beta$ to heterodimerize presents additional consequences for differential gene activation $^{14}$. To date, very little is yet known about ER- $\beta$ with respect to what genes are differentially regulated compared to $E R-\alpha$, or the functional differences of the different dimeric forms. In addition, antibodies that distinguish between the two ER forms have only recently become available. Studies of ER $\alpha$ compared to ER $\beta$ expression in endometrial tumors are just now being performed.

\section{Progesterone Receptor Isoforms}

Two isoforms of PR, PRA and PRB, are expressed in humans, and both are likely to be required for endometrial differentiation. PRA and PRB are located on the same gene and are encoded from alternative promoters to ultimately generate a $90 \mathrm{kDa}$ or $120 \mathrm{kDa}$ protein, respectively. Homo- or heterodimerization of PRA and PRB is required to form the functional transcription factor unit on DNA. Studies by Clarke and colleagues have demonstrated both isoforms are expressed in the glands and the stroma, though at different ratios: PRA may be the primary form expressed in the stroma, and PRB is the dominant form in the glandular epithelium ${ }^{15}$. The amino acid sequences of the isoforms are identical except that PRB has a longer 165 residue $\mathrm{N}$-terminus, which contains a third activation function (AF-3, Figure 1). The conserved sequences down-stream from the $\mathrm{N}$-terminus of PRB include a DNA binding domain (DBD), a hinge region with the nuclear localization sequence (NLS), a region to which co-modulators (Co- 
$\mathrm{R}$ ) bind, and the ligand binding domain (LBD) with activation function-2 (AF-2).

The unique $\mathrm{N}$-terminus of $\mathrm{PRB}$ with AF-3 encoded therein has conferred different functional characteristics on the isoforms: PRB is a stronger transcriptional activator of many genes compared to PRA ${ }^{16-18}$, but PRA apparently counters estrogen action directly by inhibiting ER function in a dominant negative manner ${ }^{17}$. In endometrial cancer cell lines, both isoforms function to enhance differentiation, with PRA inducing cell senescence and PRB inducing a secretory phenotype. While expression of either isoform in endometrial cancer cells augments sensitivity to apoptosis and inhibition of the $\mathrm{G} 1$ to $\mathrm{S}$ cell cycle transition ${ }^{19}$, with respect to growth inhibition, PRB appears to be the dominant controller of growth of human endometrial cancer cells when cultured in vitro ${ }^{20}$. Of note, PRB expression is undetectable in the poorly differentiated endometrial cancer cell lines (e.g., Hec50 and $K L E$ ), identifying a role for PRB in maintaining a differentiated phenotype ${ }^{17,18}$. In accord with that hypothesis, it has been shown that PRA and PRB or only PRA is downregulated in endometrial cancers $^{21,22}$. Several animal models have been created to identify the role of PRA and PRB in endometrial cancer ${ }^{3}$, though the data are somewhat conflicting with the function of PRB in human endometrial cancer cell lines. For example, progesterone activation of $P R B$ in the mice deficient in PRA promotes proliferation of endometrial tissue ${ }^{23}$, which results in significant endometrial hyperplasia in female $\mathrm{PRA}^{-1-}$ mice knock-out mice ${ }^{24}$. These studies are of interest but should be interpreted with caution given the differences between rodents and humans: while progesterone does induce endometrial hyperplasia in $\mathrm{PRA}^{-/-}$mice, these animals do not develop carcinoma in situ. However, it cannot be completely ruled out that PRB exerts proliferative effects in the human endometrium.

Further complicating the field, one report now indicates that commercially available antibodies against PRA/B may not bind the two isoforms with equal affinity in immunohistochemical samples, though the antibodies do have equal affinity for denatured protein (e.g., as assessed by western blotting). Moreover, many PR antibodies only recognize PRA and not PRB though the epitope is in a conserved region 25 , which suggests that earlier immunohistochemical studies of PR expression may have underestimated PRB levels ${ }^{21}$. Hence, future studies are critical to determine how differential expression of PR receptor isoforms impacts clinical outcome. These studies are necessary to fully evaluate the feasibility of hormone therapy as a treatment strategy for endometrial cancer.

\section{Androgen Receptor Variants}

Although currently in debate in the literature ${ }^{26}$, androgen receptors (ARs) have been reported to be expressed in two isoforms, the longer $B$ protein $(110 \mathrm{kD})$ and the 
shorter A protein (87 kD), the product of an $\mathrm{N}$-terminus truncation ${ }^{27}$. In vitro data suggest that the two forms are functionally equivalent in cell lines with respect to activation by androgens and anti-androgens on synthetic DNA promoters, but additional data on the gene expression profiles induced by the two forms would be helpful to confirm these initial findings 28 . Alterations in the expression of AR isoforms have been reported in colon cancer ${ }^{29}$, with the $A$ isoform predominating over the $B$ and raising the possibility that, like $P R, A R$ isoform expression may be disturbed in the process of carcinogenesis.

\section{Glucocorticoid Receptor Isoforms}

Glucocorticoid receptors (GRs) are transcribed and translated into a number of isoforms. Therefore, GRs, like PRs and ARs, exist in at least two isoforms as a result of alternative transcription and translation from the same gene. The two principal proteins that result are the $94 \mathrm{kD}$ GRA and the $91 \mathrm{kD}$ GRB. Studies now indicate that the two isoforms differ in their ability to activate transcription on consensus glucocorticoid DNA response elements: the shorter isoform, GRB, is twice as efficient at inducing transcription as the longer GRA ${ }^{30}$. Interestingly, the consensus sequences for the PR and GR DNA response elements are identical, though the actual sequences in hormone responsive gene promoters vary and may direct whether the gene is controlled by progestins through PRs or by glucocorticoids through GRs ${ }^{31}$. Interestingly, the shorter GRB resides in the nucleus in the absence of ligand, whereas GRA is normally in the cytoplasm and requires ligand for nuclear localization 30 . This differential localization in the absence of ligand is reminiscent of observations in endometrial cancer cells, where the shorter form of PR, PRA, is nuclear even in the absence of ligand (Leslie, unpublished observations), whereas the longer isoform, PRB, requires ligand or phosphorylation by MAP kinase for nuclear localization. The similarities between PR and GR isoforms are in distinction to the ER isoforms. ER- $\alpha$ and $-\beta$ are transcribed from different genes and diverge significantly in structure over much of the molecules.

\section{Activity of Steroid Receptors}

Over the past two decades, the efforts of many laboratories have been focused on identifying the mechanism(s) by which steroid receptors exert their transcriptional regulatory effects. Steroid receptors bind to specific short DNA sequences termed enhancer elements, which are found upstream of regulated genes. However, simply binding to DNA is insufficient for steroid receptors to carry out their function. Critical to the regulation of steroid response is the ability of the receptor to interact with a wide array of transcriptional co-factors. Some of these co-factors serve to enhance the activity of the receptor whereas others blunt it, either in the liganded state or when the receptor is unoccupied. The inhibitory function of co-factors ensures that the steroid receptor does not inappropriately 
activate transcription in the absence of hormone. Prevailing evidence indicates that the cell and tissue specific effects of ER (and indeed, all receptors) are due to the different of array of activating and repressing cofactors present in a given cell.

Estrogen, progesterone, glucocorticoids, and androgens act via genomic and non-genomic pathways to control cell function and proliferation. The genomic pathway leads directly to the transcription of hormone-dependent genes and is the principal and best-studied mode of action. Gene expression profiling in response to steroid hormones through their cognate receptors has provided new information on the large number of pathways controlled by these factors. Cytokines, cell adhesion molecules, growth factors and their receptors, signaling molecules, pro- and anti-apoptotic factors, DNA binding proteins, enzymes, other classes of transcription factors, and cell cycle regulators are now known to be under hormonal control 19, 20, 31-41. Hormone-dependent gene transcription results from the binding of the steroid hormones as ligands to specific nuclear receptors 42 . ER, $P R$, glucocorticoid receptor (GR), and androgen receptor (AR) are members of the super-family of steroid and thyroid hormone receptors ${ }^{43}$. They are best characterized as nuclear transcription factors responsible for binding to DNA, recruiting a protein complex of co-modulators as well as the basal transcriptional unit, and initiating the expression of hormonedependent proteins ${ }^{44}$.
Varying degrees of conservation exist among the functional domains of the receptors, as shown for PR in Figure 1. The $\mathrm{N}$-termial $\mathrm{A} / \mathrm{B}$ domain is not highly conserved but contains important activation functions (AFs) responsible for protein-protein interactions with co-activators and co-repressors that impart a positive or a negative transcriptional conformation on the receptor complex ${ }^{45}$. In contrast, the DBD is the most highly conserved region of the receptor family. This domain contains numerous basic amino acids arranged into two zinc fingers responsible for recognizing and binding to specific DNA response elements in the promoters of hormone-dependent genes. The LBD, located near the carboxyl terminus, is fairly heterogeneous among family members to allow different ligands to bind to the otherwise similar family members. In addition, the LBD contains a hormone-dependent $\mathrm{AF}$ involved in protein-protein interactions.

\section{Non-genomic effects of steroid hormones}

Non-genomic functions within the cytosol and at the cell membrane are also attributed to steroid hormones. The best studied non-genomic effects thus far is the activity of estrogen through ERs and other membrane and cytosolic receptors 46 , but ARs are also reported to be present in the membrane fraction ${ }^{47}$, indicating that the findings for estrogen may also relate to other steroid hormones. Recent evidence suggests that there are at least two non-genomic pathways by which 
estrogen acts in the membrane. First, the classic ER- $\alpha$ protein can localize to the membrane as well as the nucleus. These data suggest that estrogens activate ERs at the membrane, resulting in rapid cellular effects that may control ion fluxes and signaling pathways $48,49$. Second, it has been reported that estrogens, and to a lesser extent, partial estrogens and anti-estrogens such as tamoxifen and ICl 182780, respectively, can bind a novel membrane G-protein receptor, GPR30 50, 51. Interestingly, the transcription of GPR30 is under the control of progesterone in breast cancer cells, and is involved in progesterone as well as estrogen control of cell proliferation $52-54$. GPR30 controls the activation of the epidermal growth factor receptor (EGFR) and downstream signaling events including Ras phosphorylation ${ }^{55}$. The effects of Ras activation include the phosphorylation of proteins, such as PI3 kinase, that ultimately control apoptosis, and others, such as MAP kinases, that phosphorylate and activate a myriad of transcription factors, including the hormone receptors themselves, members of the AP-1 family, and protooncogenes such as c-Myc. Protein kinases $C$ and $A$ are also activated by non-genomic pathways of estrogen action, and these are involved in the control of intracellular calcium and $\mathrm{pH}^{55}$.

Membrane PRs and GRs have also been hypothesized to exist because progesterone and corticosteroids have a number of very rapid cellular effects, on the order of seconds and minutes, that could not occur as a result of transcription, which takes hours. A progesterone-binding protein distinct from the nuclear receptor has been identified in porcine vascular smooth muscle cells ${ }^{56}$. Most recently, a new family of membrane progesterone binding proteins with similarities to $G$ proteincoupled receptors has been cloned from the spotted seatrout, the mouse, pig, zebrafish, Xenopus, and the human 57, 58. These bind progestins with high affinity and are saturable, indicating their function as specific receptors through which progestins may exert rapid membrane and cytoplasmic effects. Classic GRs have been identified in the membranes of lymphoma cells 59, and cytoplasmic GRs and PRs may cross talk with signal transduction pathways that could initiate or enhance responses in conjunction with membrane bound growth factor receptors or G-protein receptors. Both GRs and PRs shuttle in and out of the nucleus, and PRB, for example, exists mainly in the cytoplasm in the absence of ligand in breast cancer cells 60 and in endometrial cancer cells (Leslie, unpublished observations). PRB is driven into the nucleus in the presence of progesterone or EGF by two distinct mechanisms, indicating that growth factor signaling as well as hormonal ligands may activate hormone receptors and set the stage for steroid receptor activity in the nucleus ${ }^{60}$.

Hence, the understanding of hormone effects now encompasses the nuclear receptors as activators of transcription as classically described, 
as well as cytosolic and membrane receptors (membrane-bound ERs, ARs, GRs, GPR30, G-protein like receptors for progesterone, and possibly others) through which moment by moment ion fluxes, signal transduction pathways, apoptosis, as well as the activity of other transcription factors are controlled.

\section{Expression of hormone receptors in the normal endometrium}

With respect to endometrial proliferation and differentiation, by far the best- studied steroid hormones are estrogen and progesterone. ERs are expressed in both the glandular eplithelium and the stroma in increasing concentrations as the proliferative phase of the cycle progresses. At ovulation, ERs are down-regulated in response to progesterone production from the ovary. PRs are also induced in increasing concentrations during the proliferative phase, in part due to rising estradiol levels that induce PRs through ERs. The A isoform of $P R$ predominates over the $B$ isoform throughout the menstrual cycle, particularly in the stroma 61 . However, PRBs are induced more dramatically by estradiol, particularly in the glandular epithelium. During the secretory phase of the menstrual cycle, ERs and PRs are gradually down-regulated in the glandular epithelium, but PRs are still expressed in the stroma where progesterone is critical for ongoing proliferation and the secretory response.
GRs are expressed in human and rodent endometrium, and ARs have been identified in the human and rodent ovary and uterus ${ }^{62}$. ARs are induced by estrogen and downregulated by testosterone ${ }^{63}$, though others have suggested that estradiol plus testosterone most strongly induces AR ${ }^{64}$. Progesterone has also been implicated in the induction of $A R$ in the endometrium ${ }^{65}$, most likely when it is combined with estrogen ${ }^{64}$. ARs are present in the glandular epithelium and to a greater extent in the stroma of the endometrium. The receptors are induced during the proliferative phase of the cycle, present in stable amounts during the early secretory phase, and lost in the late secretory phase of the menstrual cycle ${ }^{66}$. Androgens act through ARs in the endometrial stroma to induce the expression of prolactin, a marker for endometrial differentiation, which is also induced by progesterone through PRs 67. Androgen also inhibits the effects of estrogen, limiting proliferation in the epithelium and the stroma ${ }^{68}$, and ARs are expressed in 40 to 88 percent of endometrial cancers ${ }^{69}$. A careful balance of hormone expression in the endometrium at the distinct stages of the menstrual cycle is critical to prevent oncogenesis.

\section{Cross-talk between the endometrial glands and stroma}

The endometrium is composed of two cell types, the glandular epithelium and the stroma. Endometrial cancers arise most commonly in the glandular epithelium. However, the glands and 
stroma communicate directly, and it is likely that abnormal interactions between the two tissues may occur in the process of endometrial carcinogenesis 70 . The epithelial glands and the stroma both express ERs and PRs, and expression in both tissue types is likely to be necessary to induce normal growth and differentiation of the glandular epithelium. For example, reconstitution experiments using stromal and epithelial cells from estrogen receptor knock-out (ERKO) and normal mice demonstrate that epithelial cell proliferation in the mouse is mediated via ER action from the stroma ${ }^{70-72}$. In addition, stromal PR levels are much higher than epithelial levels at the time of implantation, making it clear that progesterone's effects at critical stages in endometrial function are mediated through the stroma ${ }^{73}$. It is predicted that some aspects of epithelial cell differentiation in response to progesterone may be mediated through stromal PRs ${ }^{74}$. Therefore, evaluation of receptor expression in the stroma as well as the glands may provide insight into the process of carcinogenesis and to the responsiveness of the tumor to progestin therapy.

\section{Steroid receptor status in endometrial cancers}

Ligand binding assays for steroid receptors as well as immunohistochemistry (IHC) have been used to determine protein levels in endometrial tumors. Most studies from the last decade use $\mathrm{IHC}$, which is well accepted as a modality to localize and semi- quantitate ERs and PRs in paraffinembedded endometrial tumor tissues. IHC allows the evaluation of multiple regions of the tumor and can be used to distinguish ERs and PRs in the glands as well as the surrounding stroma, thereby providing a significant advantage over ligand binding assays ${ }^{75}$.

Numerous studies support the finding that high ER and PR levels are associated with a well differentiated tumor phenotype. Initial work was done by the ligand binding method on protein extracts from tumors. McCarty et al studied 58 patients for histologic grade and ligand binding activity for ER and PR 76. Eighty-five percent of the well differentiated lesions demonstrated high levels of ER and PR, whereas only $13 \%$ of poorly differentiated tumors had detectable levels of ER or PR. Following 114 patients with endometrial cancer, Ehrlich et al demonstrated a reduction in PRs with poorly differentiated tumors as well as a statistical correlation between the response of the patient to progestin treatment and the presence of PRs 77 . Improved response to therapy for patients with high ERs and PRs was also documented by other ligand binding studies ${ }^{78,79}$ as well as by Carcangiu and Chambers in some of the first major reports of $\mathrm{IHC}$ for ERs and PRs in endometrial cancers ${ }^{80,81}$. In these studies, receptor status was determined by $\mathrm{IHC}$ as well as by traditional ligand binding assays on 183 tumor specimens. The correlation was very good between the techniques, and the best predictor of a good outcome was 
high ER levels by IHC. An early paper that distinguished between hormone responsive tumors (type I) and non-hormone responsive tumors (type II) demonstrated the loss of PRs in type II tumors by ligand binding ${ }^{82}$. Even in early stage and grade tumors, loss of PRs has been reported to be a predictor for adverse clinical outcome ${ }^{83,84}$. ER status by IHC was correlated with survival in a study of 78 cases of endometrial cancer ${ }^{85}$. High PR and ER levels were found to be predictive of survival and low PR levels to be predictive of lymph node metastasis in two similar IHC studies from the same laboratory ${ }^{86,87}$. In spite of the apparent usefulness of identifying receptor status in endometrial tumors as a predictor of hormonal responsiveness and good clinical outcome, more recent data cast doubt on whether receptor status is an independent predictor of recurrence. Indeed, Fanning et al studied 62 endometrial cancers for ER, PR, p53, HER-2/neu, c-myc, and additional proteins considered to be markers for proliferation ${ }^{88}$. They determined that none of the proteins identified by IHC were independently able to predict recurrence over and above the surgical stage and grade of the tumor. This suggests that more investigations are indicated, including an analysis of receptor isoforms, to more firmly establish the clinical usefulness of receptor identification in endometrial cancers.

\section{Clinical role of hormones in endometrial cancer}

Endometrial carcinogenesis is related to overexposure to estrogen that is not balanced by the differentiating effects of progesterone and potentially other steroid hormones, including androgens and glucocorticoids. The endometrium is one of the most estrogen sensitive tissues in the body and responds to estrogens with rapid cell growth: unopposed estrogen stimulation can lead to endometrial hyperplasia, cellular atypia, and endometrial cancer. Initial studies indicating that the proliferation of the endometrium was under hormonal control employed tritiated thymidine incorporation as a measure of DNA synthesis in animal models. These original data have now been supplemented by detailed investigations that show that estrogens act upon the endometrium through estrogen receptors (ERs), resulting in the induction of growth factors such as the epidermal growth factor (EGF) ${ }^{89}$, its receptor (EGFR) ${ }^{90}$, insulin-like growth factor-1 (IGF-1) 91 , and growth-enhancing protooncogenes, such as c-fos and c-myc ${ }^{92}$. ERs induce PRs through which progesterone exerts differentiating effects on the glandular epithelium and opposes the growth promoting effects of estrogen. ARs and GRs are also expressed in the endometrium and in endometrial tumors and may be involved in endometrial differentiation ${ }^{93,94}$.

\section{Role of estrogen in endometrial carcinogenesis}

Excess estrogen stimulation of the endometrium is a well-documented risk factor for endometrial cancer. Excess estrogen stimulation can be 
the result of the exogenous administration of estrogen or the endogenous production of estrogen. The best known example of exogenous estrogen administration is in the form of hormone replacement therapies (HRT). The administration of conjugated equine estrogens unopposed by progestin was once common practice for postmenopausal symptoms. It was later found to be associated with a higher rate of endometrial cancer and endometrial hyperplasia. In one study, a year of unopposed estrogen therapy resulted in $20 \%$ of patients developing endometrial hyperplasia 95. In a Swedish trial of low potency estrogen administered for the relief of urogenital symptoms, oral estriol increased the relative risk of endometrial cancer and atypical endometrial hyperplasia. The odds ratios for at least five years of estrogen therapy were $3.0 \quad(95 \%$ confidence interval, 2.0-4.4) for cancer and 8.3 (95\% confidence interval, 4.0-17.4) for atypical hyperplasia ${ }^{96}$.

The most common example of endogenous estrogen excess relates to enzymatic production within adipose tissue. Obese women demonstrate a greater capacity for the biochemical conversion of peripherally circulating androstenedione to estrone. It has been estimated that over $40 \%$ of endometrial cancer incidence can be attributed to excess body weight 97 . A European review of epidemiological data concluded that 14,000 cases of endometrial cancer each year can be attributed to obesity ${ }^{98}$. A case-control study of
Danish women supported this mechanism by showing elevated plasma levels of estradiol, free estradiol, and estrone in endometrial cancer patients when compared to control women 99 . These results were confirmed by a more recent study that found significant elevations in the odds ratio for endometrial cancer in groups of women with the highest quartiles of estradiol and estrone levels ${ }^{100}$.

There is evidence that other steps in the estrogen pathway can alter the risk for endometrial cancer. An elevated blood level of sex hormone binding globulin (SHBG) was found to reduce the risk for endometrial cancer 100, 101. SHBG binds estrogens in the circulation and renders them biologically inactive, thereby reducing estrogen effects at the target tissues. The odds ratio for cancer when compared to controls was $0.46(0.20-1.05)$ to 0.51 (0.270.95 ) in these studies ${ }^{100,101}$. Another example of estrogen pathway alteration involves the induction of hepatic cytochrome P450 enzymes in women who smoke. The increased enzyme activity results in greater clearance of estrogens from the circulation and a reduction in end organ effect ${ }^{102}$. Epidemiological studies have demonstrated a 20$30 \%$ reduction in the risk of endometrial cancer in women who smoke ${ }^{103,104 .}$

Endogenous estrogen production also occurs via autonomous synthesis within some ovarian tumors. The class of tumors most often associated with hyperestrogenism is the sex-cord 
stromal tumors. The most common sex-cord stromal tumor is the granulosa cell tumor, which occurs with an incidence of $0.99 / 100,000$ American women ${ }^{105}$. Human ovarian granulosa cells are responsible for the production of inhibin and estrogen. It is this function that may occur autonomously in women with granulosa cell tumors and lead to a hyperestrogenic state. The classic symptoms associated with a granulosa cell tumor include estrogen-stimulated end organ effects such as premature thelarche, menorrhagia, and endometrial hyperplasia as well as endometrial cancer. Endometrial cancer has been associated with granulosa cell tumors in up to $10 \%$ of cases in published clinical reviews ${ }^{105}$. In addition, Leydig cell containing tumors are found to produce testosterone. Estrone is produced by peripheral aromatase conversion of this testosterone in adipose tissues. Estrogen manifestations and endometrial cancers have been occasionally reported ${ }^{106}$.

A further example of endogenous estrogen production occurs in the polycystic ovarian syndrome (PCOS). The PCOS is recognized as a metabolic and endocrine alteration that results in, among other things, hyperandrogenism. The excess of androgens that are produced can be converted to estrone to produce an estrogen enriched environment. Epidemiological studies have shown a five-fold increase in the risk of endometrial cancer among patients with PCOS ${ }^{97}$.

\section{Progestins}

The role of progesterone in the glandular epithelium of the endometrium is primarily antagonistic to estrogen-mediated cell proliferation 107. Progestinrelated effects include the induction of endometrial cell differentiation and regulation of uncontrolled endometrial cell growth. These effects have led to significant therapeutic uses for progestins.

A consequence of the endometrium stabilizing effect of progestins has been a reduction of endometrial cancer in those taking progestin or progestin-dominant medications. An early epidemiological study of contraceptive use in Washington state found that the use of combination preparations (both estrogen and progestin components) resulted in a 50\% reduction in endometrial cancer risk when compared to the general female population. It was additionally shown that the relative risk of endometrial cancer for women using a high-dose estrogen contraceptive was 7.3 (1.438.8) compared to control women 108. In the seminal investigation of steroid hormone use in women known as the CASH study, it was found that at least 12 months of combination oral contraceptive use resulted in an age-adjusted risk for endometrial cancer of 0.6 (0.3-0.9) relative to control women ${ }^{109}$. The risk-reduction in endometrial cancer afforded by progestins has also been shown in the context of postmenopausal HRT. In the Million Women Study that was undertaken in the United Kingdom, the use of 
continuous combined preparations resulted in a relative risk of 0.71 (0.56-0.90) for endometrial cancer compared to never-users of HRT ${ }^{110}$.

Progestins have found a role in the treatment of the premalignant endometrial hyperplasias as well as early invasive endometrial cancer. This therapy has mainly been deemed an option for either younger patients that desire future fertility or patients that are medically compromised. It appears that hyperplasia and early invasive carcinoma of the endometrium retains responsiveness to progestins in a significant proportion of cases. The largest retrospective study of this treatment approach found that complete regression occurred in $94 \%$ of patients with atypical hyperplasia and $75 \%$ of patients with well-differentiated carcinoma. It was noted that nine months was the median length of treatment required to induce a remission 111 . A retrospective review of studies using 79 articles reported a $76 \%$ response rate in grade 1 endometrial cancer patients with a median time to response of 12 weeks ${ }^{112}$. A more recent prospective trial of women in Japan using $600 \mathrm{mg}$ of medroxyprogesterone acetate (MPA) daily resulted in pathologic complete responses for $82 \%$ of patients with atypical hyperplasia and $55 \%$ of patients with endometrial cancer ${ }^{113}$.

In patients with advanced or recurrent endometrial cancer, oral progestins such as megestrol acetate (MA) and MPA have been reported to demonstrate response rates around $25 \% 114,115$. These responses have predominantly occurred in PR-positive tumors and have been short-lived with median overall survival reaching 10.5 months ${ }^{115}$. The recommended dose for oral MPA in the treatment of recurrent or advanced endometrial cancer was concluded to be $200 \mathrm{mg}$ per day. Higher daily doses of MPA failed to yield improved outcomes as demonstrated by the Gynecologic Oncology Group (GOG) study that compared this regimen to $1000 \mathrm{mg}$ daily ${ }^{115}$. The major advantage of progestin-based regimens has been their tolerability with the most common side effects including weight gain in $26 \%$ and venous thrombosis in $5 \%$ of patients ${ }^{114}$.

The duration of efficacy for progestins has been relatively short with progression-free intervals ranging from 2.5 to 8.5 months; longer intervals are associated with low grade tumors that tested positive for estrogen and progesterone receptors ${ }^{116}$. The lack of prolonged responses to progestins is thought to involve progestin receptor downregulation that accompanies continuous progestin therapy ${ }^{3}$.

A critical question that must be addressed is why, unlike nonmalignant hyperplastic disorders of the endometrium, so many endometrial cancers fail to respond to the growth limiting effects of progestins. A possible explanation is that endometrial cancers downregulate PRs 117, 118, and when present, PRs are down-regulated by progestins given as therapy ${ }^{119}$ and Leslie KK, unpublished observations). In fact, expression of 
PRs has been positively correlated with a good prognosis and response to progestin treatment. The overall response rate has been reported to be $72 \%$ in patients with PR-rich tumors but only $12 \%$ in patients with PR-poor lesions ${ }^{116}$. More than 90\% of endometrial carcinomas express high levels of estrogen receptors (ERs), whereas PR levels vary. Even in the presence of ERs, some tumors do not contain PRs ${ }^{120}$. As PRs are normally up-regulated by estrogens via ERs, this implies that failure to induce PRs may be a factor in the genesis and/or progression of endometrial cancer. Loss of PR expression is likely to be the primary cause of progestin resistance in endometrial cancer, and tumors that re-grow after an initial period of regression in response to progestin down-regulate PR expression ${ }^{119}$.

The known variation in PR expression in endometrial cancer is complicated by the fact that such tumors are extremely heterogeneous ${ }^{121}$, and each tumor may be composed of multiple subpopulations of cells with high or low responsiveness to progestins ${ }^{122}$ and varying levels of PR expression. Interestingly, tumor heterogeneity and response to progestins is not necessarily predicted by the state of tumor differentiation ${ }^{122}$, so even well differentiated cancers are not predictably sensitive to progestin treatment. Even in cancers demonstrating high total PR levels, progestin treatment may leave small sub-populations of cells with low PR expression unaffected, leading to eventual treatment failures.

\section{Anti-estrogens as an endometrial cancer therapy}

Tamoxifen is a selective estrogen receptor modulator with both agonist and antagonist effects on estrogen receptors, depending on the tissue studied. It is used to advantage in breast cancer for its antagonistic effects, but is known to carry a small risk for the development of endometrial cancer ${ }^{123}$. Tamoxifen demonstrated an overall response rate of only $10 \%$ when used as a single agent in patients with advanced or recurrent endometrial carcinoma ${ }^{124}$. In light of the data regarding progesterone receptor downregulation, the GOG combined tamoxifen with MPA for a trial in a similar patient population ${ }^{125}$. Patients with advanced or recurrent endometrial cancer were administered tamoxifen, $40 \mathrm{mg}$ daily with alternating weekly cycles of MPA, $200 \mathrm{mg}$ daily. Although a higher response rate of $33 \%$ was achieved with the combination therapy, the median progression free survival was only 3 months with an overall survival of 13 months ${ }^{125}$.

\section{Aromatase inhibitors in endometrial cancer}

Aromatase inhibitors are molecules that block the subcutaneous conversion of adrenally-produced androstenedione into estrone. This leads to less estrogen stimulation of the tumor. The GOG studied the aromatase inhibitor, anastrazole, in 23 patients with endometrial cancer 126. Two patients showed a partial response (14.8\%) and the overall survival was six months. A higher 
percentage of high grade serous cancers in this study may have contributed to the low response rate and it was noted that one of the responses occurred in a patient with a PR-positive tumor. Similar results were also reported by $\mathrm{Ma}$ and colleagues in patients treated with letrozole despite the majority of specimens testing positive for ER and $P R{ }^{127}$. The response rate was $9.4 \%$ with a 6.7 month median duration of stable disease. Aromatase inhibitors have yet to prove their efficacy in the treatment of endometrial cancer.

\section{Use of gonadotropin-releasing hormone agonists}

Gonadotropin-releasing hormone $(\mathrm{GnRH})$ analogues stimulate the pituitary to produce gonadotropins, which subsequently leads to a dramatic suppression of sex steroid hormone production in the ovaries. These agents are also thought to act directly on $\mathrm{GnRH}$ receptors found in endometrial tumors. Small studies showed conflicting results with a trial of goserelin reporting a 35\% response rate but a trial of leuprolide reporting no responders 128,129 . The GOG undertook to further evaluate the $\mathrm{GnRH}$ analogue goserelin acetate in women with recurrent endometrial cancer. The agent was deemed ineffective in this population due to an $11 \%$ (4-27\%) response rate, with a median PFS of 1.9 months and an overall survival of 7.3 months ${ }^{130}$.

\section{Conclusions}

Over the past 30 years, we have gained a great appreciation for the role of steroid hormones in maintaining endometrial integrity and preventing development of cancer. A shift in the careful balance of proproliferative estrogen and differentiating progesterone is an underlying cause of cancer. Despite this understanding, the current treatment strategies for endometrial cancer are not as effective in promoting disease-free survival and preventing recurrence as in other types of hormone-dependent cancer, such as breast and prostate cancer. Future therapeutic strategies for endometrial cancer should focus on ways to re-establish the hormonal balance.

\section{References}

1. Menasce LP, White GR, Harrison CJ, Boyle JM. Localization of the estrogen receptor locus (ESR) to chromosome 6q25.1 by FISH and a simple post-FISH banding technique. Genomics. 1993;17(1):263-265.

2. Kuiper GG, Enmark E, Pelto-Huikko $M$, Nilsson $S$, Gustafsson JA. Cloning of a novel receptor expressed in rat prostate and ovary. Proc Natl Acad Sci $U$ S A. 1996;93(12):5925-5930.

3. Yang S, Thiel KW, Leslie KK. Progesterone: the ultimate endometrial tumor suppressor. Trends Endocrinol Metab. 2011;22(4):145-152.

4. Wei LL, Miner R. Evidence for the existence of a third progesterone receptor protein in human breast cancer cell line T47D. Cancer Res. 1994;54(2):340-343.

5. Greene GL, Gilna P, Waterfield M, Baker A, Hort Y, Shine J. Sequence and expression of human estrogen 
receptor complementary DNA. Science. 1986;231(4742):11501154.

6. Picard D. Chaperoning steroid hormone action. Trends Endocrinol Metab. 2006;17(6):229-235.

7. Ricketts D, Turnbull L, Ryall G, Bakhshi R, Rawson NS, Gazet JC, Nolan C, Coombes RC. Estrogen and progesterone receptors in the normal female breast. Cancer Res. 1991;51(7):1817-1822.

8. Horwitz KB, Koseki Y, McGuire WL. Estrogen control of progesterone receptor in human breast cancer: role of estradiol and antiestrogen. Endocrinology. 1978;103(5):17421751.

9. Sluyser M. Role of estrogen receptor variants in the development of hormone resistance in breast cancer. Clin Biochem. 1992;25(6):407-414.

10. Leygue E, Dotzlaw H, Lu B, Glor C, Watson $\mathrm{PH}$, Murphy LC. Estrogen receptor beta: mine is longer than yours? J Clin Endocrinol Metab. 1998;83(10):3754-3755.

11. Kuiper GG, Carlsson B, Grandien K, Enmark E, Haggblad J, Nilsson S, Gustafsson JA. Comparison of the ligand binding specificity and transcript tissue distribution of estrogen receptors alpha and beta. Endocrinology. 1997;138(3):863870.

12. Lubahn DB, Moyer JS, Golding TS, Couse JF, Korach KS, Smithies O. Alteration of reproductive function but not prenatal sexual development after insertional disruption of the mouse estrogen receptor gene. Proc Natl Acad Sci U S A. 1993;90(23):11162-11166.

13. Lazennec G, Ediger TR, Petz LN, Nardulli AM, Katzenellenbogen BS. Mechanistic aspects of estrogen receptor activation probed with constitutively active estrogen receptors: correlations with DNA and coregulator interactions and receptor conformational changes. Mol Endocrinol. 1997;11(9):13751386.
14. Lewin DI. Researchers get down to the alphas and betas of estrogen's effects. J NIH Res. 1997;9:23-25.

15. Mote PA, Balleine RL, McGowan EM, Clarke CL. Colocalization of progesterone receptors $A$ and $B$ by dual immunofluorescent histochemistry in human endometrium during the menstrual cycle. J Clin Endocrinol Metab. 1999;84(8):2963-2971.

16. Jacobsen BM, Richer JK, Schittone SA, Horwitz KB. New human breast cancer cells to study progesterone receptor isoform ratio effects and ligand-independent gene regulation. J Biol Chem. 2002;277(31):2779327800.

17. Leslie KK, Kumar NS, Richer J, Owen G, Takimoto G, Horwitz KB, Lange $C$. Differential expression of the $A$ and $B$ isoforms of progesterone receptor in human endometrial cancer cells. Only progesterone receptor $B$ is induced by estrogen and associated with strong transcriptional activation. Ann N Y Acad Sci. 1997;828:17-26.

18. Kumar NS, Richer J, Owen G, Litman E, Horwitz KB, Leslie KK. Selective down-regulation of progesterone receptor isoform $B$ in poorly differentiated human endometrial cancer cells: implications for unopposed estrogen action. Cancer Res. 1998;58(9):1860-1865.

19. Dai D, Wolf DM, Litman ES, White MJ, Leslie KK. Progesterone inhibits human endometrial cancer cell growth and invasiveness: downregulation of cellular adhesion molecules through progesterone $B$ receptors. Cancer Res. 2002;62(3):881-886.

20. Smid-Koopman E, Blok LJ, Kuhne LC, Burger CW, Helmerhorst TJ, Brinkmann AO, Huikeshoven FJ. Distinct functional differences of human progesterone receptors $A$ and $B$ on gene expression and growth regulation in two endometrial carcinoma cell lines. J Soc Gynecol Investig. 2003;10(1):49-57.

21. Arnett-Mansfield RL, deFazio A, Wain GV, Jaworski RC, Byth K, 
Mote PA, Clarke CL. Relative expression of progesterone receptors $A$ and $B$ in endometrioid cancers of the endometrium. Cancer Res. 2001;61(11):4576-4582.

22. Fujimoto J, Ichigo $S$, Hori $M$, Nishigaki M, Tamaya T. Expression of progesterone receptor form $A$ and $B$ mRNAs in gynecologic malignant tumors. Tumour Biol. 1995;16(4):254-260.

23. Mulac-Jericevic $B$, Mullinax RA, DeMayo FJ, Lydon JP, Conneely OM. Subgroup of reproductive functions of progesterone mediated by progesterone receptor- $B$ isoform. Science. 2000;289(5485):17511754.

24. Lydon JP, DeMayo FJ, Funk CR, Mani SK, Hughes AR, Montgomery CA, Jr., Shyamala G, Conneely OM, O'Malley BW. Mice lacking progesterone receptor exhibit pleiotropic reproductive abnormalities. Genes Dev. 1995;9(18):2266-2278.

25. Mote PA, Johnston JF, Manninen T, Tuohimaa P, Clarke CL. Detection of progesterone receptor forms $A$ and $B$ by immunohistochemical analysis. J Clin Pathol. 2001;54(8):624-630.

26. Gregory CW, He B, Wilson EM. The putative androgen receptor-A form results from in vitro proteolysis. J Mol Endocrinol. 2001;27(3):309319.

27. Tilley WD, Marcelli M, Wilson JD, McPhaul MJ. Characterization and expression of a cDNA encoding the human androgen receptor. Proc Natl Acad Sci U S A. 1989;86(1):327331.

28. Gao T, McPhaul MJ. Functional activities of the $A$ and $B$ forms of the human androgen receptor in response to androgen receptor agonists and antagonists. Mol Endocrinol. 1998;12(5):654-663.

29. Catalano MG, Pfeffer $U$, Raineri $M$, Ferro P, Curto A, Capuzzi P, Corno F, Berta L, Fortunati N. Altered expression of androgen-receptor isoforms in human colon-cancer tissues. Int J Cancer. 2000;86(3):325-330.
30. Yudt MR, Cidlowski JA. The glucocorticoid receptor: coding a diversity of proteins and responses through a single gene. Mol Endocrinol. 2002;16(8):1719-1726.

31. Wan Y, Nordeen SK. Overlapping but distinct gene regulation profiles by glucocorticoids and progestins in human breast cancer cells. Mol Endocrinol. 2002;16(6):1204-1214.

32. Mutter GL, Baak JP, Fitzgerald JT, Gray R, Neuberg D, Kust GA, Gentleman R, Gullans SR, Wei LJ, Wilcox M. Global expression changes of constitutive and hormonally regulated genes during endometrial neoplastic transformation. Gynecol Oncol. 2001;83(2):177-185.

33. Kao LC, Tulac S, Lobo S, Imani B, Yang JP, Germeyer A, Osteen K, Taylor RN, Lessey BA, Giudice LC. Global gene profiling in human endometrium during the window of implantation. Endocrinology. 2002;143(6):2119-2138.

34. Kramer PR, Wray S. 17-Betaestradiol regulates expression of genes that function in macrophage activation and cholesterol homeostasis. J Steroid Biochem Mol Biol. 2002;81(3):203-216.

35. Levenson AS, Svoboda KM, Pease KM, Kaiser SA, Chen B, Simons LA, Jovanovic BD, Dyck PA, Jordan VC. Gene expression profiles with activation of the estrogen receptor alpha- selective estrogen receptor modulator complex in breast cancer cells expressing wild-type estrogen receptor. Cancer Res. 2002;62(15):4419-4426.

36. Naciff JM, Jump ML, Torontali SM, Carr GJ, Tiesman JP, Overmann GJ, Daston GP. Gene expression profile induced by 17alpha-ethynyl estradiol, bisphenol $\mathrm{A}$, and genistein in the developing female reproductive system of the rat. Toxicol Sci. 2002;68(1):184-199.

37. Richer JK, Jacobsen BM, Manning NG, Abel MG, Wolf DM, Horwitz KB. Differential gene regulation by the two progesterone receptor isoforms in human breast cancer cells. J Biol Chem. 2002;277(7):5209-5218. 
38. Rockett JC, Kavlock RJ, Lambright CR, Parks LG, Schmid JE, Wilson VS, Wood C, Dix DJ. DNA arrays to monitor gene expression in rat blood and uterus following 17betaestradiol exposure: biomonitoring environmental effects using surrogate tissues. Toxicol Sci. 2002;69(1):49-59.

39. Wan Y, Nordeen SK. Identification of genes differentially regulated by glucocorticoids and progestins using a Cre/loxP-mediated retroviral promoter-trapping strategy. J Mol Endocrinol. 2002;28(3):177-192.

40. Weston GC, Haviv I, Rogers PA. Microarray analysis of VEGFresponsive genes in myometrial endothelial cells. Mol Hum Reprod. 2002;8(9):855-863.

41. Salleh MN, Caldwell J, Carmichael PL. A comparison of gene expression changes in response to diethylstilbestrol treatment in wildtype and p53+/- hemizygous knockout mice using focussed arrays. Toxicology. 2003;185(12):49-57.

42. Jensen EV, DeSombre ER. Estrogen-receptor interaction. Science. 1973;182(108):126-134.

43. Evans RM. The steroid and thyroid hormone receptor superfamily. Science. 1988;240(4854):889-895.

44. Onate SA, Tsai SY, Tsai MJ, O'Malley BW. Sequence and characterization of a coactivator for the steroid hormone receptor superfamily. Science. 1995;270(5240):1354-1357.

45. McDonnell DP, Chang CY, Norris JD. Development of peptide antagonists that target estrogen receptor- cofactor interactions. J Steroid Biochem Mol Biol. 2000;74(5):327-335.

46. Ho KJ, Liao JK. Nonnuclear actions of estrogen. Arterioscler Thromb Vasc Biol. 2002;22(12):1952-1961.

47. McCann JP, Mayes JS, Hendricks $\mathrm{GR}$, Harjo JB, Watson GH. Subcellular distribution and glycosylation pattern of androgen receptor from sheep omental adipose tissue. J Endocrinol. 2001;169(3):587-593.
48. Singleton DW, Feng $\mathrm{Y}$, Burd CJ, Khan SA. Nongenomic activity and subsequent $\mathrm{c}$-fos induction by estrogen receptor ligands are not sufficient to promote deoxyribonucleic acid synthesis in human endometrial adenocarcinoma cells. Endocrinology. 2003;144(1):121128.

49. Harvey BJ, Doolan CM, Condliffe SB, Renard C, Alzamora R, Urbach $\mathrm{V}$. Non-genomic convergent and divergent signalling of rapid responses to aldosterone and estradiol in mammalian colon. Steroids. 2002;67(6):483-491.

50. Filardo EJ. Epidermal growth factor receptor (EGFR) transactivation by estrogen via the G-protein-coupled receptor, GPR30: a novel signaling pathway with potential significance for breast cancer. J Steroid Biochem Mol Biol. 2002;80(2):231-238.

51. Filardo EJ, Quinn JA, Frackelton $\mathrm{AR}$, Jr., Bland KI. Estrogen action via the $G$ protein-coupled receptor, GPR30: stimulation of adenylyl cyclase and cAMP-mediated attenuation of the epidermal growth factor receptor-to-MAPK signaling axis. Mol Endocrinol. 2002;16(1):7084.

52. Ahola TM, Alkio N, Manninen $\mathrm{T}$, Ylikomi T. Progestin and $\mathrm{G}$ proteincoupled receptor 30 inhibit mitogenactivated protein kinase activity in MCF-7 breast cancer cells. Endocrinology. 2002;143(12):46204626.

53. Ahola TM, Manninen T, Alkio N, Ylikomi T. G protein-coupled receptor 30 is critical for a progestininduced growth inhibition in MCF-7 breast cancer cells. Endocrinology. 2002;143(9):3376-3384.

54. Ahola TM, Purmonen S, Pennanen P, Zhuang YH, Tuohimaa P, Ylikomi T. Progestin upregulates G-proteincoupled receptor 30 in breast cancer cells. Eur J Biochem. 2002;269(10):2485-2490.

55. Prossnitz ER, Oprea TI, Sklar LA, Arterburn JB. The ins and outs of GPR30: a transmembrane estrogen 
receptor. J Steroid Biochem Mol Biol. 2008;109(3-5):350-353.

56. Falkenstein E, Meyer C, Eisen C, Scriba PC, Wehling M. Full-length cDNA sequence of a progesterone membrane-binding protein from porcine vascular smooth muscle cells. Biochem Biophys Res Commun. 1996;229(1):86-89.

57. Zhu Y, Rice CD, Pang Y, Pace M, Thomas $P$. Cloning, expression, and characterization of a membrane progestin receptor and evidence it is an intermediary in meiotic maturation of fish oocytes. Proc Natl Acad Sci U S A. 2003;100(5):22312236.

58. Zhu Y, Bond J, Thomas $P$. Identification, classification, and partial characterization of genes in humans and other vertebrates homologous to a fish membrane progestin receptor. Proc Natl Acad Sci U S A. 2003;100(5):2237-2242.

59. Chen F, Watson CS, Gametchu B. Association of the glucocorticoid receptor alternatively-spliced transcript $1 \mathrm{~A}$ with the presence of the high molecular weight membrane glucocorticoid receptor in mouse lymphoma cells. J Cell Biochem. 1999;74(3):430-446.

60. Qiu M, Olsen A, Faivre E, Horwitz $\mathrm{KB}$, Lange CA. Mitogen-activated protein kinase regulates nuclear association of human progesterone receptors. Mol Endocrinol. 2003;17(4):628-642.

61. Mote PA, Balleine RL, McGowan EM, Clarke CL. Heterogeneity of progesterone receptors $A$ and $B$ expression in human endometrial glands and stroma. Hum Reprod. 2000;15 Suppl 3:48-56.

62. Hirai $M$, Hirata $S$, Osada $T$, Hagihara K, Kato J. Androgen receptor mRNA in the rat ovary and uterus. J Steroid Biochem Mol Biol. 1994;49(1):1-7.

63. Fujimoto J, Nishigaki $M$, Hori $M$, Ichigo S, Itoh T, Tamaya $\mathrm{T}$. Biological implications of estrogen and androgen effects on androgen receptor and its mRNA levels in human uterine endometrium.
Gynecol Endocrinol. 1995;9(2):149155.

64. Adesanya-Famuyiwa $\mathrm{OO}$, Zhou J, Wu G, Bondy C. Localization and sex steroid regulation of androgen receptor gene expression in rhesus monkey uterus. Obstet Gynecol. 1999;93(2):265-270.

65. Slayden OD, Nayak NR, Burton KA, Chwalisz K, Cameron ST, Critchley HO, Baird DT, Brenner RM. Progesterone antagonists increase androgen receptor expression in the rhesus macaque and human endometrium. J Clin Endocrinol Metab. 2001;86(6):2668-2679.

66. Mertens HJ, Heineman MJ, Koudstaal J, Theunissen P, Evers $\mathrm{JL}$. Androgen receptor content in human endometrium. Eur $\mathrm{J}$ Obstet Gynecol Reprod Biol. 1996;70(1):11-13.

67. Narukawa $S$, Kanzaki $H$, Inoue $T$, Imai $\mathrm{K}$, Higuchi $\mathrm{T}$, Hatayama $\mathrm{H}$, Kariya M, Mori T. Androgens induce prolactin production by human endometrial stromal cells in vitro. J Clin Endocrinol Metab. 1994;78(1):165-168.

68. Brenner RM, Slayden OD, Critchley $\mathrm{HO}$. Anti-proliferative effects of progesterone antagonists in the primate endometrium: a potential role for the androgen receptor. Reproduction. 2002;124(2):167-172.

69. Brys M, Semczuk A, Baranowski W, Jakowicki J, Krajewska WM. Androgen receptor (AR) expression in normal and cancerous human endometrial tissues detected by RTPCR and immunohistochemistry. Anticancer Res. 2002;22(2A):10251031.

70. Cooke PS, Buchanan DL, Young P, Setiawan T, Brody J, Korach KS, Taylor J, Lubahn DB, Cunha GR. Stromal estrogen receptors mediate mitogenic effects of estradiol on uterine epithelium. Proc Natl Acad Sci U S A. 1997;94(12):6535-6540.

71. Cooke PS, Buchanan DL, Lubahn DB, Cunha GR. Mechanism of estrogen action: lessons from the estrogen receptor-alpha knockout mouse. Biol Reprod. 1998;59(3):470-475. 
72. Buchanan DL, Kurita T, Taylor JA, Lubahn DB, Cunha GR, Cooke PS. Role of stromal and epithelial estrogen receptors in vaginal epithelial proliferation, stratification, and cornification. Endocrinology. 1998;139(10):4345-4352.

73. Wathes DC, Smith HF, Leung ST, Stevenson KR, Meier S, Jenkin G. Oxytocin receptor development in ovine uterus and cervix throughout pregnancy and at parturition as determined by in situ hybridization analysis. J Reprod Fertil. 1996;106(1):23-31.

74. Rider V, Kimler BF, Justice WM. Progesterone-growth factor interactions in uterine stromal cells. Biol Reprod. 1998;59(3):464-469.

75. Soper JT, Segreti EM, Novotny DB, Mutch D, Creasman WT, McCarty $\mathrm{KS}$, Jr. Estrogen and progesterone receptor content of endometrial carcinomas: comparison of total tissue versus cancer component analysis. Gynecol Oncol. 1990;36(3):363-368.

76. McCarty KS, Jr., Barton TK, Fetter BF, Creasman WT, McCarty KS, Sr. Correlation of estrogen and progesterone receptors with histologic differentiation in endometrial adenocarcinoma. Am J Pathol. 1979;96(1):171-183.

77. Ehrlich CE, Young PC, Cleary RE. Cytoplasmic progesterone and estradiol receptors in normal, hyperplastic, and carcinomatous endometria: therapeutic implications. Am J Obstet Gynecol. 1981;141(5):539-546.

78. Kauppila AJ, Isotalo HE, Kivinen ST, Vihko RK. Prediction of clinical outcome with estrogen and progestin receptor concentrations and their relationships to clinical and histopathological variables in endometrial cancer. Cancer Res. 1986;46(10):5380-5384.

79. Ingram SS, Rosenman J, Heath R, Morgan TM, Moore D, Varia M. The predictive value of progesterone receptor levels in endometrial cancer. Int J Radiat Oncol Biol Phys. 1989;17(1):21-27.
80. Carcangiu ML, Chambers JT, Voynick IM, Pirro M, Schwartz PE. Immunohistochemical evaluation of estrogen and progesterone receptor content in 183 patients with endometrial carcinoma. Part I: Clinical and histologic correlations. Am J Clin Pathol. 1990;94(3):247254.

81. Chambers JT, Carcangiu ML, Voynick IM, Schwartz PE. Immunohistochemical evaluation of estrogen and progesterone receptor content in 183 patients with endometrial carcinoma. Part II: Correlation between biochemical and immunohistochemical methods and survival. Am J Clin Pathol. 1990;94(3):255-260.

82. Deligdisch L, Holinka CF. Progesterone receptors in two groups of endometrial carcinoma. Cancer. 1986;57(7):1385-1388.

83. Creasman WT. Prognostic significance of hormone receptors in endometrial cancer. Cancer. 1993;71(4 Suppl):1467-1470.

84. Tornos C, Silva EG, el-Naggar A, Burke TW. Aggressive stage I grade 1 endometrial carcinoma. Cancer. 1992;70(4):790-798.

85. Pertschuk LP, Masood S, Simone J, Feldman JG, Fruchter RG, Axiotis $\mathrm{CA}$, Greene GL. Estrogen receptor immunocytochemistry in endometrial carcinoma: a prognostic marker for survival. Gynecol Oncol. 1996;63(1):28-33.

86. Fukuda K, Mori M, Uchiyama M, Iwai $\mathrm{K}$, Iwasaka $\mathrm{T}$, Sugimori $\mathrm{H}$. Prognostic significance of progesterone receptor immunohistochemistry in endometrial carcinoma. Gynecol Oncol. 1998;69(3):220-225.

87. Iwai K, Fukuda K, Hachisuga T, Mori M, Uchiyama M, Iwasaka T, Sugimori $\mathrm{H}$. Prognostic significance of progesterone receptor immunohistochemistry for lymph node metastases in endometrial carcinoma. Gynecol Oncol. 1999;72(3):351-359.

88. Fanning J, Brown S, Phibbs G, Kramer $\mathrm{T}$, Zaher A. Immunohistochemical evaluation is 
not prognostic for recurrence in fully staged high-risk endometrial cancer. Int J Gynecol Cancer. 2002;12(3):286-289.

89. Huet-Hudson YM, Chakraborty C, De SK, Suzuki Y, Andrews GK, Dey SK. Estrogen regulates the synthesis of epidermal growth factor in mouse uterine epithelial cells. Mol Endocrinol. 1990;4(3):510-523.

90. Lingham RB, Stancel GM, LooseMitchell DS. Estrogen regulation of epidermal growth factor receptor messenger ribonucleic acid. Mol Endocrinol. 1988;2(3):230-235.

91. Murphy LJ, Murphy LC, Friesen HG. Estrogen induces insulin-like growth factor-I expression in the rat uterus. Mol Endocrinol. 1987;1(7):445-450.

92. Weisz A, Bresciani F. Estrogen induces expression of $\mathrm{C}$-fos and Cmyc protooncogenes in rat uterus. Mol Endocrinol. 1988;2(9):816-824.

93. Tuckerman EM, Okon MA, Li T, Laird SM. Do androgens have a direct effect on endometrial function? An in vitro study. Fertil Steril. 2000;74(4):771-779.

94. Brenner RM, West NB, McClellan MC. Estrogen and progestin receptors in the reproductive tract of male and female primates. Biol Reprod. 1990;42(1):11-19.

95. Woodruff JD, Pickar JH. Incidence of endometrial hyperplasia in postmenopausal women taking conjugated estrogens (Premarin) with medroxyprogesterone acetate or conjugated estrogens alone. The Menopause Study Group. Am J Obstet Gynecol. 1994;170(5 Pt 1):1213-1223.

96. Weiderpass E, Baron JA, Adami $\mathrm{HO}$, Magnusson $\mathrm{C}$, Lindgren $\mathrm{A}$, Bergstrom R, Correia N, Persson I. Low-potency oestrogen and risk of endometrial cancer: a case-control study. Lancet. 1999;353(9167):1824-1828.

97. Kaaks R, Lukanova A, Kurzer MS. Obesity, endogenous hormones, and endometrial cancer risk: a synthetic review. Cancer Epidemiol Biomarkers Prev. 2002;11(12):15311543.
98. Bergstrom A, Pisani $P$, Tenet $V$, Wolk A, Adami HO. Overweight as an avoidable cause of cancer in Europe. Int J Cancer. 2001;91(3):421-430.

99. Nyholm HC, Nielsen AL, Lyndrup J, Dreisler A, Hagen C, Haug E. Plasma oestrogens in postmenopausal women with endometrial cancer. $\mathrm{Br} \mathrm{J}$ Obstet Gynaecol. 1993;100(12):1115-1119.

100. Lukanova A, Zeleniuch-Jacquotte A, Lundin E, Micheli A, Arslan AA, Rinaldi S, Muti $P$, Lenner $P$, Koenig $\mathrm{KL}$, Biessy $\mathrm{C}$, Krogh V, Riboli $\mathrm{E}$, Shore RE, Stattin $P$, Berrino $F$, Hallmans G, Toniolo P, Kaaks R. Prediagnostic levels of C-peptide, IGF-I, IGFBP -1, -2 and -3 and risk of endometrial cancer. Int $\mathrm{J}$ Cancer. 2004;108(2):262-268.

101. Potischman N, Hoover RN, Brinton LA, Siiteri P, Dorgan JF, Swanson $\mathrm{CA}$, Berman ML, Mortel R, Twiggs LB, Barrett RJ, Wilbanks GD, Persky V, Lurain JR. Case-control study of endogenous steroid hormones and endometrial cancer. J Natl Cancer Inst. 1996;88(16):1127-1135.

102. Mueck AO, Seeger H. Smoking, estradiol metabolism and hormone replacement therapy. Curr Med Chem Cardiovasc Hematol Agents. 2005;3(1):45-54.

103. Al-Zoughool M, Dossus L, Kaaks R, Clavel-Chapelon $F$, Tjonneland A, Olsen A, Overvad K, Boutron-Ruault MC, Gauthier E, Linseisen J, Chang-Claude J, Boeing $\mathrm{H}$, Schulz M, Trichopoulou A, Chryssa T, Trichopoulos D, Berrino F, Palli D, Mattiello A, Tumino R, Sacerdote C, Bueno-de-Mesquita HB, Boshuizen HC, Peeters PH, Gram IT, Braaten $\mathrm{T}$, Lund $\mathrm{E}$, Chirlaque MD, Ardanaz E, Agudo A, Larranaga N, Quiros JR, Berglund G, Manjer J, Lundin E, Hallmans $G$, Khaw KT, Bingham S, Allen N, Key $T$, Jenab M, Cust AE, Rinaldi S, Riboli E. Risk of endometrial cancer in relationship to cigarette smoking: results from the EPIC study. Int J Cancer. 2007;121(12):2741-2747. 
104. Zhou B, Yang L, Sun Q, Cong R, Gu $H$, Tang $N$, Zhu $H$, Wang $B$. Cigarette smoking and the risk of endometrial cancer: a metaanalysis. Am J Med. 2008;121(6):501-508 e503.

105. Schumer ST, Cannistra SA. Granulosa cell tumor of the ovary. J Clin Oncol. 2003;21(6):1180-1189.

106. Outwater EK, Wagner BJ, Mannion C, McLarney JK, Kim B. Sex cordstromal and steroid cell tumors of the ovary. Radiographics. 1998;18(6):1523-1546.

107. Clarke CL, Sutherland RL. Progestin regulation of cellular proliferation. Endocr Rev. 1990;11(2):266-301.

108. Weiss NS, Sayvetz TA. Incidence of endometrial cancer in relation to the use of oral contraceptives. N Engl J Med. 1980;302(10):551-554.

109. Combination oral contraceptive use and the risk of endometrial cancer. The Cancer and Steroid Hormone Study of the Centers for Disease Control and the National Institute of Child Health and Human Development. JAMA. 1987;257(6):796-800.

110. Beral V, Bull D, Reeves G. Endometrial cancer and hormonereplacement therapy in the Million Women Study. Lancet. 2005;365(9470):1543-1551.

111. Randall TC, Kurman RJ. Progestin treatment of atypical hyperplasia and well-differentiated carcinoma of the endometrium in women under age 40. Obstet Gynecol. 1997;90(3):434-440.

112. Ramirez PT, Frumovitz M, Bodurka DC, Sun CC, Levenback C. Hormonal therapy for the management of grade 1 endometrial adenocarcinoma: a literature review. Gynecol Oncol. 2004;95(1):133-138.

113. Ushijima K, Yahata H, Yoshikawa H, Konishi I, Yasugi T, Saito T, Nakanishi T, Sasaki H, Saji F, Iwasaka T, Hatae M, Kodama S, Terakawa N, Yaegashi N, Hiura M, Sakamoto A, Tsuda H, Fukunaga M, Kamura T. Multicenter phase II study of fertility-sparing treatment with medroxyprogesterone acetate for endometrial carcinoma and atypical hyperplasia in young women. J Clin Oncol. 2007;25(19):2798-2803.

114. Lentz SS, Brady MF, Major FJ, Reid GC, Soper JT. High-dose megestrol acetate in advanced or recurrent endometrial carcinoma: a Gynecologic Oncology Group Study. J Clin Oncol. 1996;14(2):357-361.

115. Thigpen JT, Brady MF, Alvarez RD, Adelson MD, Homesley HD, Manetta A, Soper JT, Given FT. Oral medroxyprogesterone acetate in the treatment of advanced or recurrent endometrial carcinoma: a dose-response study by the Gynecologic Oncology Group. J Clin Oncol. 1999;17(6):1736-1744.

116. Ehrlich CE, Young PC, Stehman FB, Sutton GP, Alford WM. Steroid receptors and clinical outcome in patients with adenocarcinoma of the endometrium. Am J Obstet Gynecol. 1988;158(4):796-807.

117. Leslie KK, Stein MP, Kumar NS, Dai $\mathrm{D}$, Stephens J, Wandinger-Ness A, Glueck DH. Progesterone receptor isoform identification and subcellular localization in endometrial cancer. Gynecol Oncol. 2005;96(1):32-41.

118. Singh M, Zaino RJ, Filiaci VJ, Leslie KK. Relationship of estrogen and progesterone receptors to clinical outcome in metastatic endometrial carcinoma: A Gynecologic Oncology Group Study. Gynecologic Oncology. 2007; 106(2):325-333.

119. Satyaswaroop PG. Development of a preclinical model for hormonal therapy of human endometrial carcinomas. Ann Med. 1993;25(2):105-111.

120. Polczaski CE, Satyaswaroop PG, Mortel R. Hormonal interactions in gynecologic malignancies. In: Hoskins WJ, Perez CA, Young RC, eds. Principles and practice of gynecologic oncology. Philadelphia: Lippincott-Raven; 1997.

121. Luo W, Wu F, Atlas SR, Pickett G, Leslie KK, Dai D. Defining genetic intra-tumor heterogeneity: a chronological annotation of mutational pathways Proc Obstet Gynecol. 2010;1(1):Article 9. 
122. Siracky J, Schreiner P, Siracka E, Matoska J. Cell proliferation kinetics and nuclear morphology in endometrial cancer under progesteron treatment. Neoplasma. 1978;25(5):535-539.

123. Fisher B, Costantino JP, Redmond CK, Fisher ER, Wickerham DL, Cronin WM. Endometrial cancer in tamoxifen-treated breast cancer patients: findings from the National Surgical Adjuvant Breast and Bowel Project (NSABP) B-14. J Natl Cancer Inst. 1994;86(7):527-537.

124. Thigpen T, Brady MF, Homesley HD, Soper JT, Bell J. Tamoxifen in the treatment of advanced or recurrent endometrial carcinoma: a Gynecologic Oncology Group study. J Clin Oncol. 2001;19(2):364-367.

125. Whitney CW, Brunetto VL, Zaino RJ, Lentz SS, Sorosky J, Armstrong DK, Lee RB. Phase II study of medroxyprogesterone acetate plus tamoxifen in advanced endometrial carcinoma: a Gynecologic Oncology Group study. Gynecol Oncol. 2004;92(1):4-9.

126. Rose PG, Brunetto VL, VanLe L, Bell J, Walker JL, Lee RB. A phase II trial of anastrozole in advanced recurrent or persistent endometrial carcinoma: a Gynecologic Oncology Group study. Gynecol Oncol. 2000;78(2):212-216.
127. Ma BB, Oza A, Eisenhauer $E$, Stanimir G, Carey M, Chapman W, Latta E, Sidhu K, Powers J, Walsh W, Fyles A. The activity of letrozole in patients with advanced or recurrent endometrial cancer and correlation with biological markers-a study of the National Cancer Institute of Canada Clinical Trials Group. Int J Gynecol Cancer. 2004;14(4):650-658.

128. Gallagher CJ, Oliver RT, Oram DH, Fowler CG, Blake PR, Mantell BS, Slevin ML, Hope-Stone HF. A new treatment for endometrial cancer with gonadotrophin releasinghormone analogue. $\mathrm{Br} \mathrm{J}$ Obstet Gynaecol. 1991;98(10):1037-1041.

129. Covens A, Thomas $G$, Shaw $P$, Ackerman I, Osborne R, Lukka H, Carey M, Franssen E, Roche K. A phase II study of leuprolide in advanced/recurrent endometrial cancer. Gynecol Oncol. 1997;64(1):126-129.

130. Asbury RF, Brunetto VL, Lee RB, Reid G, Rocereto TF. Goserelin acetate as treatment for recurrent endometrial carcinoma: a Gynecologic Oncology Group study. Am J Clin Oncol. 2002;25(6):557560. 